Transportation Research Forum

Book Review: Traffic Jam: Ten Years of 'Sustainable' Transport in the UK

Book Editors(s): Iain Docherty and Jon Shaw

Review Author(s): Gabriel Roth

Source: Journal of the Transportation Research Forum, Vol. 48, No. 3 (Fall 2009), pp. 135-136

Published by: Transportation Research Forum

Stable URL: http://www.trforum.org/journal

The Transportation Research Forum, founded in 1958, is an independent, nonprofit organization of transportation professionals who conduct, use, and benefit from research. Its purpose is to provide an impartial meeting ground for carriers, shippers, government officials, consultants, university researchers, suppliers, and others seeking exchange of information and ideas related to both passenger and freight transportation. More information on the Transportation Research Forum can be found on the Web at www.trforum.org. 
Docherty, Iain, and Shaw, Jon, eds. Traffic Jam: Ten Years of 'Sustainable' Transport in the UK. Bristol, UK: The Policy Press, 2008. ISBN 9781847420732 (hard cover).

\section{Traffic Jam}

\section{by Gabriel Roth}

Mainly because of difficulties in dealing with motor vehicles, the transport situation in Britain since the second World War has not been a happy one. Rising incomes enabled increasing numbers of people to buy cars, but governments failed to provide the policies or infrastructure to accommodate those cars or the freight vehicles flooding the roads. While vehicle ownership is private, the provision of roads, under both Conservative and Labour governments, is (as this reviewer at least sees it) socialistic, resulting in the consequences often associated with socialism: queuing, congestion, environmental degradation and inadequate investment. In the same period (1945-2005), railway services declined, ceased being financially solvent, and were taken over by government.

In 1997 a new Labour government came to power. Because (under the leadership of Tony Blair) it reformed its party policies, it called itself "New Labour." It quickly set to work devising policies for "integrated and sustainable" transport systems to improve accessibility and the environment and to reduce pollution and greenhouse gas emissions. The policies resulting from these deliberations were summarized in a 1998 white paper with the title "A New Deal for Transport: Better for Everyone." A more honest title might have been "A New Deal for Transport: Better for Everyone Except Road Users."

The purpose of Traffic Jam is to assess transport developments in the United Kingdom. in the decade following the publication of $A$ New Deal for Transport. To quote from the editors' Preface:

This book is about transport developments in the UK since the publication of the landmark White Paper, A new deal for transport, in 1998. The state of British transport had become unacceptable according to the incoming Labour government (and many others), and ministers were to improve considerably our transport systems and seek to change the way we travel. Key to this strategy was persuading us all to be more sustainable by using 'our cars a little less and public transport a little more.'

The book's 11 chapters are contributed by 15 "experienced transport academics," following a foreword by journalist Christian Wolmar which accuses the New Labour politicians of lacking the "backbone" required to address "the fundamental issues." The book consists of three parts:

"Part One: Policy and politics," consists of two chapters: an introduction by the editors, and a discussion of the relevance to transport reform of New Labour's devolution of significant transport decisions to lower-level governments in Northern Ireland, Scotland, Wales and to administrative "regions" in England.

"Part Two: Progress in policy implementation" is the core of the book. It consists of six chapters, each dealing with a separate transport mode: roads; railways; buses and light rail; walking and cycling; air travel; and ports and shipping.

"Part Three: Ten years since A new deal for transport - signposts to the UK's transport future?" consists of a chapter on London's transport; a chapter examining U.K. transport within a European perspective; and a reflective concluding chapter by Prof. Phil Goodwin, who chaired the panel which offered New Labour expert advice on preparing its new transport policies.

As the book is about the implementation of New Labour's 1998 transport policy, a description of that policy would have been helpful. The policy's flavor is probably reflected in Goodwin's footnote: 
Pedestrianisation, traffic calming, traffic management used to optimize rather than maximise traffic flow, the reallocation of scarce road space to the most needy or efficient claimants on it, the promotion of walking, cycling and public transport, the use of land-use planning to reduce unnecessary travel, the use of prices that reflect the costs of congestion and environmental effects, and tackling the psychological or 'soft' influences on travel attitudes and choices.

The book offers many acute insights. In Chapter 3, for example, Graham Parkhurst and Geoff Dudley deal with "roads and traffic." The chapter starts by attacking the "predict and provide" policy ascribed to previous governments, which they describe as "calculating how much unconstrained demand for road travel exists and adopting policy measures and providing funding streams to deliver the required capacity."

"Predict and provide" is easy to attack. One alternative to it would have been to constrain demand by applying the market approach of "price, predict, and provide what users are prepared to pay for," but this would require a national road charging system. The authors stress that "the failure of the government to embrace a national system of road user charging" was "a key failure of policy." They also recognize that the introduction of cost-based road use charging would strengthen the case for additional road capacity because "if motorists pay tolls intended to reduce congestion ... they will expect some of the funds to be spent on new road construction." They mention, but do not question, Scotland's target "to reduce road traffic to 2001 levels by 2021," a target unlikely to be reached (in this reviewer's opinion) without impoverishing the populace.

The authors write well about the problems of implementing a socialistic, "environmental" transport policy but they do not question the recommendations made in the 1998 white paper. Some of the unexplored issues are:

- Did it make sense to expand the UK's rail system rather than its road system?

- Might it have been better to improve public transport by spending money on buses rather than on passenger trains?

- What is "sustainability" and to what extent can it be enhanced by using "cars a little less and public transport a little more"?

- What might be the costs and benefits of less travel?

- The justification of the taxes and subsidies in New Labour's transport policy.

As the authors favor "integrated" transport policies, it is curious that they themselves omit to apply a key feature of integration: comparisons of alternatives on the basis of common assumptions. Thus, the chapters on roads and railways provide no comparisons between these two modes, and the chapter on buses and light rail (trams) also lacks such a comparison and appears to assume that the only disadvantage of light rail is its high cost. The possibilities of high-quality, unsubsidized, public transport by minibuses and shared taxis are not discussed.

The inability of the New Labour government, even with its huge parliamentary majority, to implement its environmental transport policy is clearly demonstrated by this valuable book. It is therefore essential reading for transport officials and planners, for example those in the Obama administration, which is designing its own policies to improve "livability," reduce travel and (as said by U.S. Secretary of Transportation Ray LaHood) "coerce people out of their cars."

To this reviewer, the chief value of Traffic Jam may lie in the demonstration that it is difficult for democratic governments to change travel behavior by regulation and exhortation, and that the familiar tools of the market economy - charges based on costs, and investment guided by profitability — might have provided the government better tools to achieve its objectives, which seem to be shared by its intelligent and well-read authors.

Gabriel Roth, a research fellow at the Independent Institute, has been following British transport policy for some fifty years. He is the author of Paying for Roads: The Economics of Traffic Congestion (1967); Roads in the Market Economy (1996); and editor of the award-winning Street Smart - Competition, Entrepreneurship and the Future of Roads (2006). 